\title{
ANALISA HASIL PENGOLAHAN CITRA TERRASAR-X DAN LANDSAT 8 UNTUK PEMETAAN GEOLOGI LEMBAR MOJOKERTO (1508-62) JAWA TIMUR
}

\author{
Yulianti Puspitasari ${ }^{1)}$, Bangun Muljo Sukojo ${ }^{1)}$, (pranta $^{2)}$ \\ 1) Jurusan Teknik Geomatika, FTSP, ITS, \\ ${ }^{2)}$ Pusat Survey Geologi Badan Geologi Kementerian Energi dan Sumber Daya Mineral \\ Email: bangunms@gmail.com
}

\begin{abstract}
Abstrak. Peta geologi merupakan peta yang sangat dibutuhkan dalam berbagai hal seperti perencanaan dan pembangunan contohnya waduk, jembatan, jalan, terowongan dan lainnya. Peta yang dibutuhkan dalam hal ini tentunya adalah peta dengan skala menengah yaitu skala 1:50.000 (Noor,2011). Namun karena saat ini peta geologi yang tersedia masih skala kecil yaitu skala 1:250.000 sampai 1:100.000, tentu harus dilaksanakan proses pemetaan untuk menghasilkan skala menengah. Jika pemetaan geologi dilakukan secara manual untuk memetakan dengan skala 1:50.000, bukan hanya membutuhkan waktu yang sangat lama namun juga membutuhkan sumber daya manusia yang banyak. Salah satu cara yang dapat dilakukan adalah memetakan geologi menggunakan metode dan data penginderaan jauh. Data yang digunakan adalah citra Landsat 8 yang memiliki resolusi spektral sedang, citra TerraSAR-X Ortho Rectifiied Radar Image dan Digital Surface Model yang memiliki resolusi spasial tinggi. Data tersebut dilakukan proses pengabungan dan dilakukan analisis untuk mendapatkan formasi batuan di wilayah penelitian. Analisa tersebut menggunakan unsur interpretasi citra (rona/warna, tekstur, pola, bentuk) ditambah dengan unsur morfologi dan pola aliran sungai. Analisa ini juga membutuhkan data tambahan berupa peta geologi 1:100.000 dan data lapangan berupa titik pengamatan. Hasil dari penelitian ini berupa peta geologi hasil interpretasi citra skala 1:50.000 yang berisi formasi batuan. Hasil interpretasi dari citra Landsat dan citra TerraSAR-X menghasilkan formasi-formasi batuan di antaranya: Formasi Ledok (Tml), Formasi Lidah (Qtl), Formasi Mundu (Tpm), Formasi Kabuh (Qpk), Endapan Aluvium (Qa), Formasi Notopuro (Qpn), Formasi Sonde (Tpso), Formasi Kalibeng (Tmpk), Formasi Pucangan (Qtp).

Kata Kunci: penginderaan jauh; citra landsat 8; citra TerraSAR-X; pemetaan geologi
\end{abstract}

\begin{abstract}
Geological map is a map that is needed in a variety of things such as planning and development for example, dams, bridges, roads, tunnels, and others. Map is needed in this case certainly is a middle-scale maps with a scale of 1: 50,000 (Noor, 2011). However, because of the current geological maps are available is still small scale is a scale of $1: 250,000$ and 1: 100,000, would have implemented a process to produce medium-scale mapping. If the geological mapping is done manually to map with a scale of 1: 50,000 not only requires a very long time, but also requires a lot of human resources. One way to do is to map the geological methods and remote sensing data. The data used was Landsat 8, which has a moderate spectral resolution, TerraSAR-X image of Ortho Rectifiied Radar Image and Digital Surface Models that have a high spatial resolution. Such data merging process is carried out and analyzed to get the rock formations in the study area. The analysis uses the elements of image interpretation (tone/color, texture, pattern, shape) coupled with elements of morphology and river flow patterns. This analysis also require additional data in the form of geological maps 1: 100,000 and field data such as observation points. Results of this research is a geological interpretation map image scale of 1: 50,000 which contains rock formations. Interpretation of Landsat image and the image of TerraSAR-X delivers rock formations include: Formation Ledok (TML), the Formation Tongue (QTL), Formation Mundu (Tpm), Formation Kabuh (Qpk), Deposition Alluvium (Qa), the Formation Notopuro ( Qpn), Formation Sonde (Tpso), Formation Kalibeng (Show at startup), the Formation Pucangan (QTP).

Keywords: remote sensing; Landsat imagery 8; TerraSAR-X imagery; geological mapping
\end{abstract}

\section{PENDAHULUAN}

Peta geologi merupakan peta yang sangat dibutuhkan dalam hal perencanaan dan pembangunan seperti waduk, industri, terowongan, jembatan, jalan dan lainnya memerlukan data geologi, karena bangunan tersebut harus dibangun di atas permukaan bumi. Selain itu juga digunakan untuk ekplorasi sumber daya mineral dan industri, kawasan rawan bencana geologi (gempa, tsunami, letusan gunung api, 
longsor), transportasi dan komunikasi (rancangan jaringan jalan, listrik, pipa dan jaringan kabel telepon. Dalam rangka mempercepat peningkatan informasi dibidang geologi guna keperluan tersebut, maka perlu untuk merencanakan dan melaksanakan kegiatan pemetaan dalam skala peta yang lebih rinci (peta skala 1:50.000), sedangkan peta yang ada masih berskala 1:250.000-1:100.000. Namun hal pembuatan peta geologi 1:50.000 terkendala dengan lamanya waktu yang dibutuhkan untuk melakukan pekerjaan pemetaan geologi seluruh wilayah Indonesia apabila dikerjakan dengan menggunakan metode survei lapangan dalam skala tersebut. Selain itu tentunya juga terkait masalah tersedianya sumber daya manusia yang mencukupi untuk melaksanakan survei dan pemetaan geologi lapangan. Salah satu cara yang dapat ditempuh untuk memetakan seluruh wilayah Indonesia dalam waktu yang lebih singkat adalah dengan melakukan pemetaan geologi berbasis data penginderaan jauh.

Lembar 1508-62 berada di daerah perbatasan 4 kabupaten di Jawa Timur yaitu Kabupaten Mojokerto, Kabupaten Jombang, Kabupaten Gresik dan Kabupaten Lamongan. Wilayah ini mengalami ketimpangan ekonomi jika dibandingkan dengan daerah yang berada di pusat kabupaten, sehingga dengan percepatan kegiatan pemetaan wilayah ini, diharapkan dapat mempercepat pembangunan ekonomi di daerah tersebut.

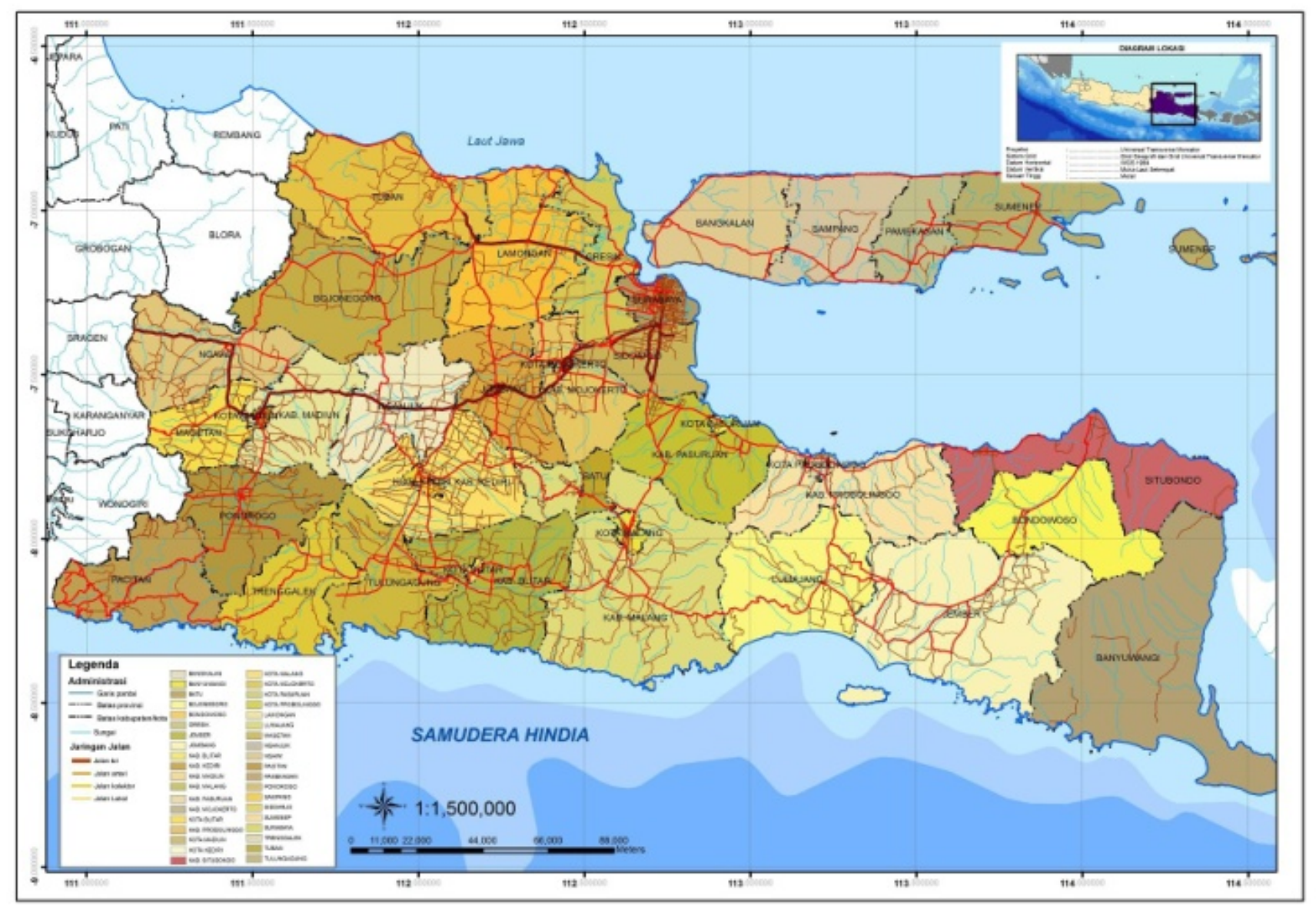

Gambar 1. Lokasi Penelitian Lembar 1508-62

(sumber:http://navperencanaan.com/appe/peta/viewmapprov_code=jatim)

Keterangan :

$=$ lokasi penelitian 


\section{Tujuan}

Tujuan penelitian adalah pemetaan geologi skala 1:50.000, lembar 1508-62 daerah perbatasan 4 kabupaten di Jawa Timur yaitu Kabupaten Mojokerto, Kabupaten Jombang, Kabupaten Gresik dan Kabupaten Lamongan dengan cara menggunakan metode dan data penginderaan jauh citra Landsat 8 yang memiliki resolusi spektral sedang, citra TerraSAR-X Ortho Rectifiied Radar Image dan Digital Surface Model yang memiliki resolusi spasial tinggi.

\section{METODOLOGI}

\section{Lokasi Penelitian}

Lokasi penelitian terletak pada Lembar 1508-62 Peta RBI, yang secara geografis terletak pada $112^{\circ} 15^{\prime} 0^{\prime \prime}$ hingga $112^{\circ} 30^{\prime} 0^{\prime \prime}$ Bujur Timur dan $7^{\circ} 15^{\prime} 0^{\prime \prime}$ hingga $7^{\circ} 30^{\prime} 0^{\prime \prime}$ Lintang Selatan. Gambar 1 merupakan gambar dari lokasi penelitian.

\section{Metodologi Penelitian}

Dalam penelitian ini, tahapan penelitian dibagi menjadi 4 tahapan, yaitu:

1. tahap persiapan yang merupakan tahap mengumpulan data dan studi literatur;

2. tahap pengolahan data;

3. tahap analisa dan

4. tahap pembuatan laporan dan pembuatan layout peta geologi hasil intepretasi citra.

\section{Tahap Pengolahan Data}

Adapun proses pengolahan data yang dilakukan tertuang pada diagram alir pengolahan data Gambar 2. Penjelasan dari diagram alir pengolahan data adalah sebagai berikut :

1. Citra yang digunakan dalam penelitian ini adalah citra TerraSAR-X ORRI, citra TerraSAR-X DSM (Digital Surface Model) dan citra Landsat 8.

2. Langkah pertama adalah melakukan proses color composit pada citra Landsat 8.

3. Langkah selanjutnya adalah melakukan cropping area atau pemotongan citra sesuai area yang akan digunakan pada masing-masing citra baik Citra Landsat 8, Citra TerraSAR-X ORRI ataupun Citra TerraSAR-X Digital Surface Model.
4. Kemudian melakukan koreksi geometrik pada citra yang akan digunakan, agar koordinat pada citra sama dengan koordinat geografis. Data yang digunakan untuk melakukan koreksi geometrik adalah data titik Ground Control Point (GCP).

5. Pada data citra TerraSAR-X DSM dilakukan proses Shaded Relief yang bertujuan untuk memunculkan relief permukaan bumi.

6. Setelah itu pada citra landsat yang telah terkoreksi dilakukan proses transformasi dari RGB ( Red Green Blue) ke IHS ( Hue Saturation Intensity).

7. Proses selanjutnya adalah proses image fusion atau penggabungan antara dua citra yang memiliki resolusi spasial dan spektral yang berbeda untuk mendapatkan resolusi yang paling baik spasial dan spektralnya. Image fusion dilakukan pada citra Landsat 8 dengan citra TerraSAR-X ORRI.

8. Kemudian citra TerraSAR-X ORRI dan citra Landsat 8 yang telah digabung melalui proses image fusion, digabungkan dengan citra TerraSAR-X Digital Surface Model dengan cara menempelkan kedua citra tersebut.

9. Langkah selanjutnya dilakukan intepretasi citra secara manual, yaitu intepretasi data penginderaan jauh yang mendasarkan pada pengenalan ciri obyek secara keruangan (spasial) dengan menggunakan unsur-unsur intepretasi citra antara lain adalah rona / warna, tekstur, bentuk, pola ukuran, letak, asiosiasi kenampakan obyek. Selain itu, intepretasi citra juga menggunakan unsur-unsur lainnya seperti morfologi dan pola aliran sungai. Dalam proses ini digunakan data pendukung adalah peta Geologi 1:100.000 dan data groundtruth.

10. Dilakukan proses analisa antara hasil intepretasi citra dengan peta geologi skala 1:100.000 Lembar Mojokerto dari Badan Geologi.

11. Tahap selanjutnya adalah melakukan proses kartografi untuk membuat layout peta.

12. Hasil dari pengolahan data adalah Peta Geologi. 


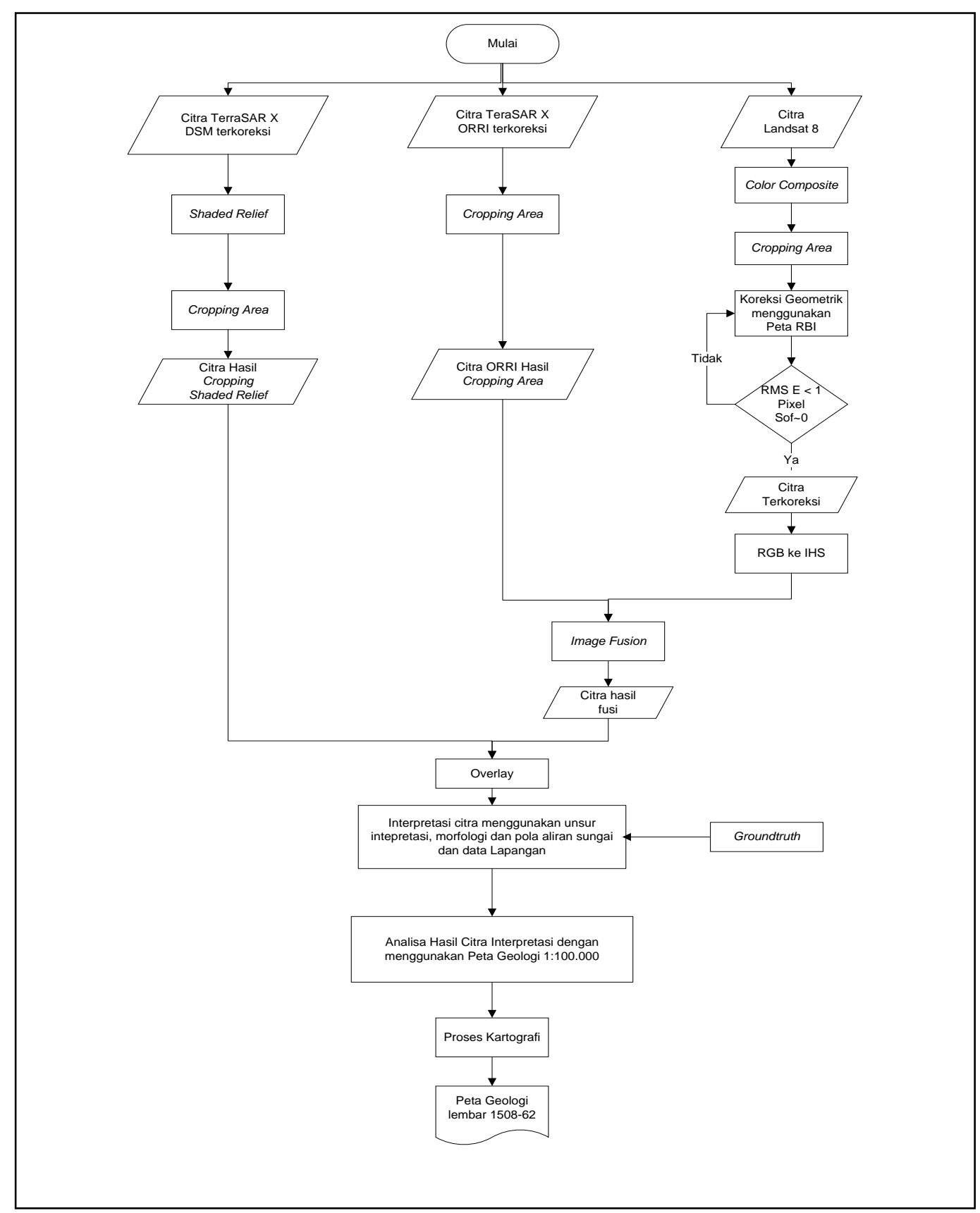

Gambar 2. Diagram Alir Pengolahan Data

\section{HASIL DAN PEMBAHASAN}

Koreksi Geometrik dan Perhitungan Srenght of Figure (SoF) pada Citra Landsat 8

Pada proses koreksi geometrik pada penelitian ini menggunakan citra Landsat 8 yang diambil pada tanggal 28 Juli 2013. Sebelum dilakukan koreksi geometrik dilakukan proses cropping (pemotongan citra). Citra Landsat 8 yang digunakan berada pada part 118 dan raw 85. Proses geometrik dilakukan dengan cara image to image yaitu dengan menggunakan peta yang telah memiliki koordinat. Peta yang digunakan disini adalah Peta Rupa Bumi Indonesia (RBI) yang telah ditampilkan, yaitu RBI lembar 1508-621, lembar 1508-622, lembar 1508-623, dan lembar 1508-624. Sistem proyeksi yang digunakan pada penelitian ini adalah datum World Geodetic System 1984 (WGS 84). Sedangkan sistem proyeksi yang digunakan adalah Universal Transvers Mechanic (UTM) dengan zona 49 South. 
Titik Ground Control Point yang digunakan adalah 9 titik GCP, dengan nilai kesalahan Root Mean Square (RMS) pada saat proses koreksi geometrik adalah 0,486 piksel. Toleransi dari nilai kesalahan pada RMS Error adalah 1 piksel [3]. Sehingga koreksi geometrik pada penelitian ini dikatakan berhasil karena nilai RMS Error kurang dari 1 piksel.
Desain jaring titik-titik GCP diatas kemudian dilakukan perhitungan Srenght of Figure (SOF) sebagai berikut:

$$
\begin{array}{ll}
\text { Jumlah Baseline } & =17 \\
\text { Jumlah Titik } & =9 \\
\text { N Ukuran } & =\text { Jumlah Baseline } \times 3=51 \\
\text { N Parameter } & =\text { Jumlah Titik } \times 3=27 \\
\text { U } & =\text { N Ukuran }-\mathrm{N} \text { Parameter }=24 \\
\text { Besar SoF } & =\frac{\operatorname{Trace}\left(\left(A^{T} A\right)^{-1}\right)}{u}=0,1033
\end{array}
$$

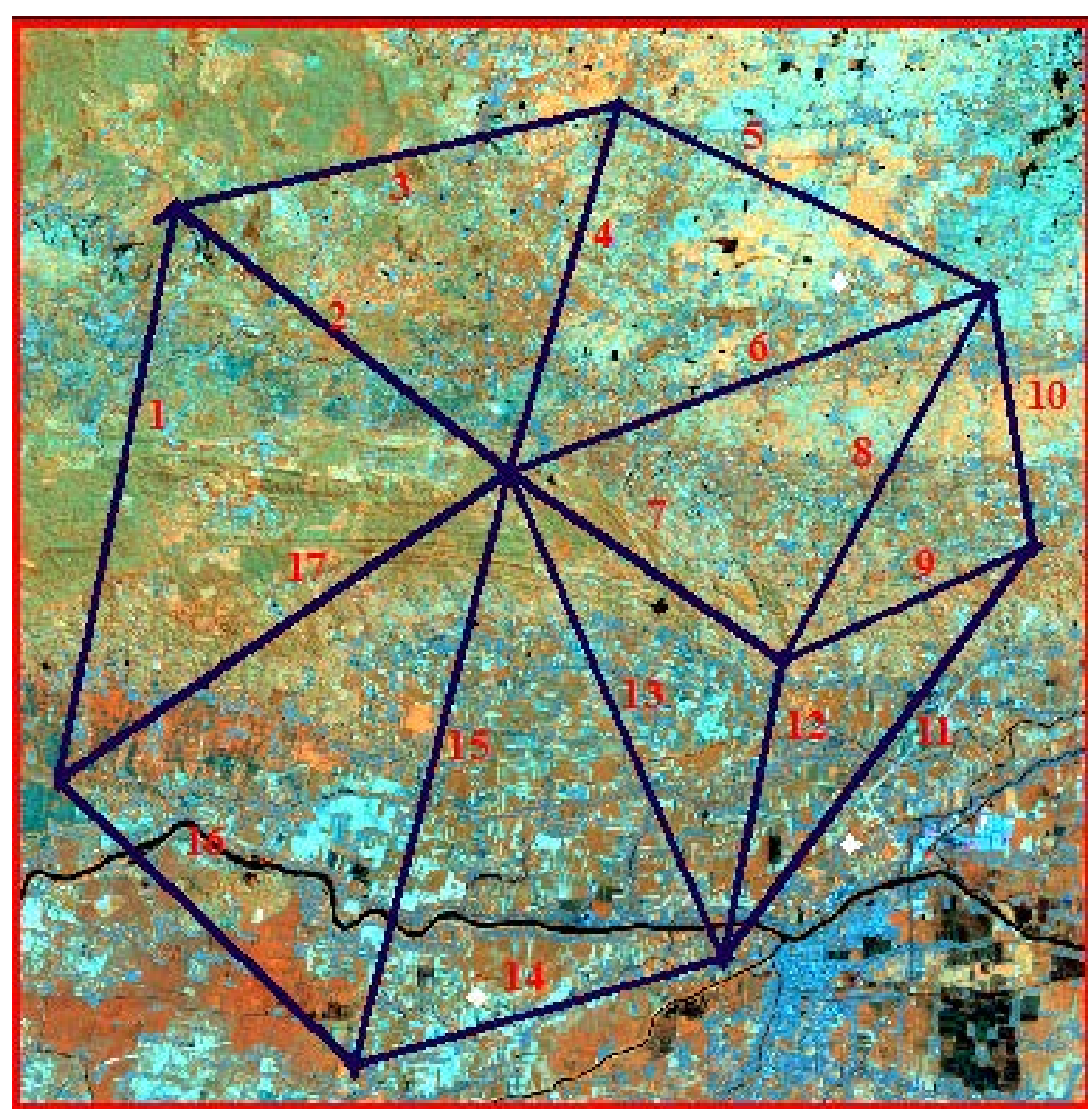

Gambar 3. Sebaran Titik GCP dan Desain Jaring

Nilai SoF yang dihasilkan jaring di atas telah masuk toleransi yang disyaratkan yaitu kurang dari 1 , sehingga desain jaring SoF dianggap kuat.

\section{Citra Landsat 8 dan TerraSAR-X}

Citra TerraSAR-X yang dipakai dalam penelitian ini telah mengalami koreksi geometrik sebelumnya. Sehingga tidak dilakukan koreksi geometrik lagi. Citra TerraSAR-X yang digunakan yaitu Citra
TerraSAR-X Orto Rectified Radar Image dan Citra TerraSAR-X Digital Surface Model.

Pada Citra TerraSAR-X Digital Surface Model dilakukan proses sun shading untuk memperlihatkan morfologi daerah studi menggunakan software ER Mapper dengan sudut elevasi $45^{\circ}$ dan sudut inklinasi $45^{\circ}$. Kemudian dilakukan cropping (pemotongan wilayah penelitian). Sedangkan untuk citra ORRI hanya 
dilakukan proses cropping. Pada citra Landsat 8 dilakukan proses color composite, kemudian dilakukan cropping daerah penelitian dan dilakukan koreksi geometri.

Setelah ini citra Landsat 8 digabung (fusi) dengan Citra TerraSAR-X ORRI agar didapatkan citra yang mempunyai nilai resolusi spektral yang tinggi (dari citra Landsat 8) dan nilai resolusi spasial yang tinggi pula (dari Citra TerraSAR-X ORRI). Kemudian ditempelkan dengan hasil sun shading Citra TerraSAR-X DSM dan diatur tingkat transparansinya dengan menggunakan ArcGIS 10. Selanjutnya dilakukan proses interpretasi citra.

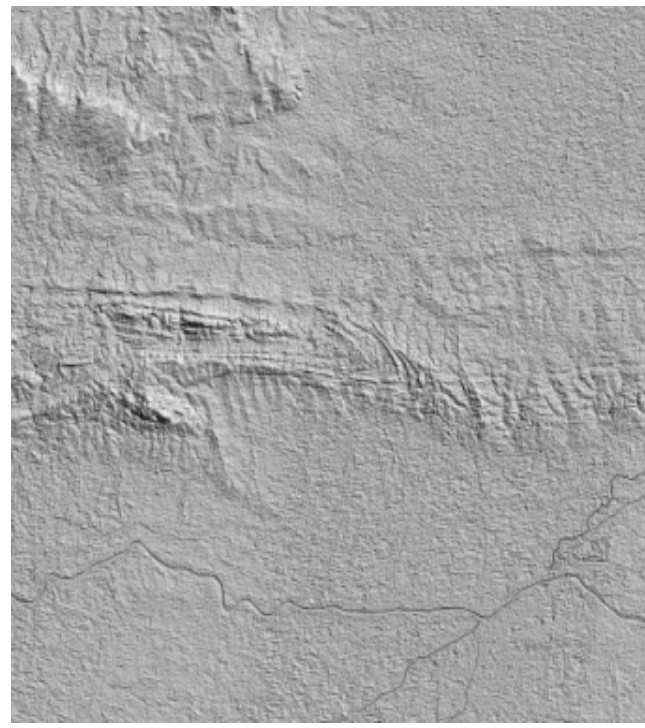

(a)

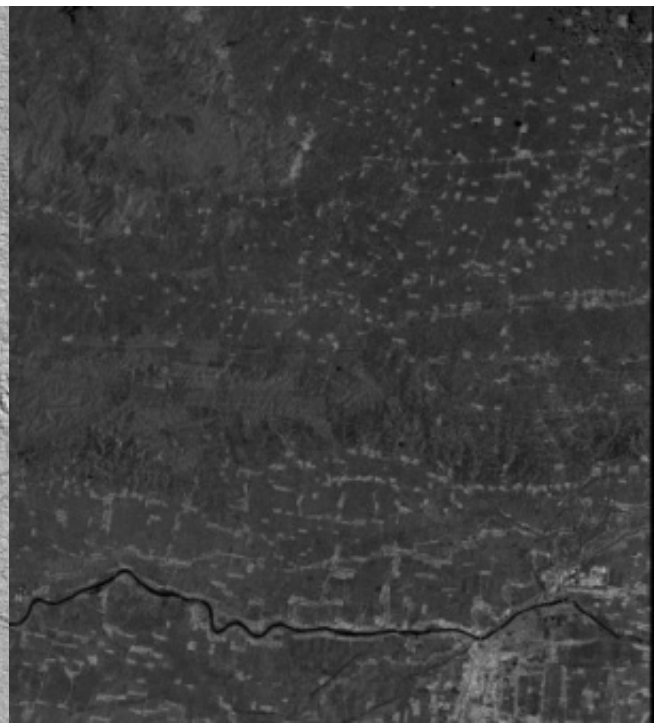

(b)

Gambar 4. (a) Citra TerraSaAR-X Digital Surface Model

(b) Citra TerraSaAR-X Ortho Rectified Radar Image

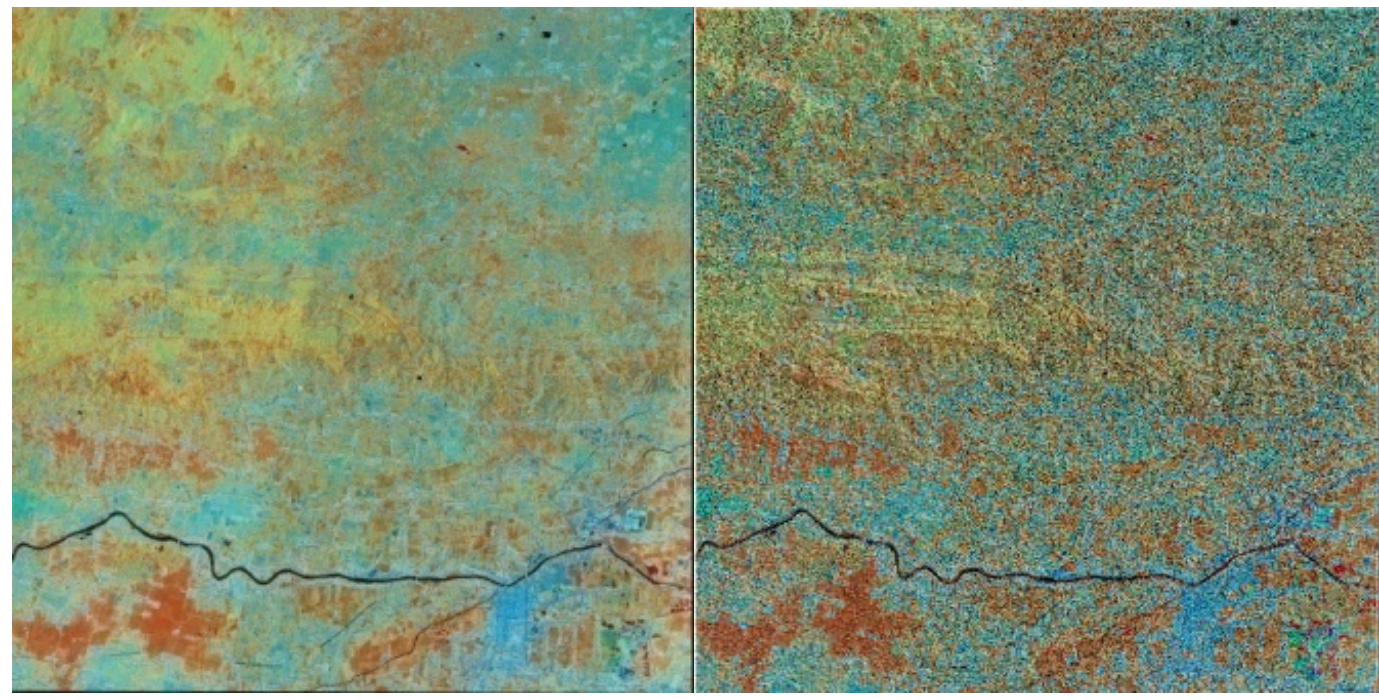

(a)

(b)

Gambar 5. (a) Image Fusion Landsat 8 dengan Citra TerraSaAR-X Ortho Rectified Radar Image

(b) Overlay antara Citra Hasil Image Fusion dengan TerraSaAR-X Digital Surface Mode 


\section{Geologi Regional}

Pada peta geologi 1:100.000 wilayah lembar 1508-62 di dominasi oleh batuan yang terbentuk pada zaman tersier dan kuarter.

- Bagian Tengah dan Utara banyak terdapat lipatan-lipatan.

- Bagian Selatan didominasi oleh endapan alluvium dengan morfologi yang datar.

- Bagian Tengah dan Barat Daya didominasi dengan morfologi bergelombang sampai perbukitan terjal.

- Bagian Timur Laut didominasi dengan endapan alluvium dengan morfologi datar.

Pada daerah Barat Daya dari lembar ini terdapat

Formasi Ledok dan Mundu (zaman Tersier) dan Formasi Lidah ( zaman Kuarter).

\section{Formasi Batuan}

1. Formasi Notopuro (Qpn)

Penelitian pada hasil overlay antara kedua citra formasi ini mempunyai kenampakan warna merah, jingga, biru, dan hijau dengan dominasi warna merah paling banyak. Pada kombinasi tersebut memperlihatkan tekstur yang bervariasi dari tekstur halus sampai sedang. Pola yang dimiliki formasi ini tidak seragam. Ukuran dari formasi ini kecil dan berapa di tengah-tengah endapan Fluvial (Qf).

Formasi ini terletak di dekat Sungai Brantas, yaitu di Kecamatan Sumobito, Kesamben, Tembelang, Magersari, Puri, dan Bangsal. Morfologi formasi ini, bagian tengahnya lebih rendah dibandingkan tepiannya karena pola aliran sungai yang menuju ke bagian tengah. Sedangkan pola aliran yang dimiliki oleh formasi ini adalah pola aliran sentripetal dengan pola aliran sungai menuju ke tengah formasi.

Formasi Notopuro memiliki litologi penyusun yang terdiri dari breksi lahar berseling dengan batu pasir tufaan dan konglomerat vulkanik (Noya dkk., 1992).

Formasi Notopuro berada pada Formasi Kabuh dengan tidak selaras. Formasi terdiri dari breksi vulkanik, tuf, tufaan baru pasir yang terendap pada Pleistosen akhir. Hubungan yang tidak selaras dengan batuan di bawahnya mengakibatkan lipatan antikli pada zona Kendeng.

Formasi ini memiliki beberapa titik pengamatan antara lain titik 08TS112, 08MR025. Titik-titik penelitian ini mendiskripsikan batuan pada Formasi Notopuro dengan warna abu-abu kecoklatan, keras, porositas buruk, dengan masa dasar pasir berbutir sedang dan fragmen gamping dan mineral kwarsa, bentuk butir menyudut tanggung sampai dengan membundar, pemilahan sedang, kemas terbuka, tersemenkan silika, karbonatan.

2. Formasi Lidah (Qtl)

Pada hasil overlay antara citra Landsat 8 dan Citra TerraSAR-X formasi ini mempunyai kenampakan warna hijau dan merah kecoklatan berseling warna biru muda. Pada formasi ini memiliki tekstur bervariasi dari halus sampai sedang. Pola dari formasi ini tidak teratur. Formasi ini memiliki pola aliran sungai dendritik. Bentuk morfologi daerah ini datar sampai bergelombang dikarenakan daerah ini berada di antara formasi yang memiliki morfologi yang terjal yaitu Tml (Formasi Ledok) dan formasi yang memiliki morfologi datar yaitu Qa (Endapan Aluvial).

Formasi ini terdiri dari beberapa macam batuan antara lain: batu lempung bersisipkan batu pasir gampingan dan batu gamping (Noya dkk.,1992). Formasi ini terbentuk pada masa Neozoikum zaman Quarter. Formasi ini berada di Kecamatan Sabeng dan Kecamatan Mantup. Formasi ini terdiri dari beberapa macam batuan antara bagian tengah terdapat Formasi Sonde, (terbentuk zaman Tersier) dan Formasi Kabuh, formasi Pucangan dan Formasi Lidah (zaman Kuarter)

Formasi Lidah terdapat pada dua zona yaitu zona Rembang dan zona Kendeng. Pada zona Kendeng, Formasi Lidah dikenal dengan susunan lempung dari Formasi Pucangan. Sedangkan pada zona Rembang dinamakan Merge Ton atau disebut lempung biru.

Formasi Lidah berkembang pada zona Kendeng bagian Timur dan bagian Barat dan 
Timur dari zona Rembang. Formasi ini terdiri dari batu lumpur abu-abu kebiruan. Formasi ini memiliki ketebalan 300-550 m. Pada bagian Timur zona Kendeng, perbedaan ditandai dengan berubahnya struktur antara bagian atas formasi Lidah dan bagian bawah Formasi Pucangan. Hubungan antara Formasi Lidah dan Formasi Atasangin adalah selaras.

Beberapa titik pengamatan yang berada di Formasi Lidah, antara lain adalah 08MR126, 08MR127 dan 08MR128 memiliki karakteristik berwarna abu - abu kecoklatan, berbutir halus, keras.

3. Formasi Ledok (Tml)

Pada hasil kombinasi kedua citra yaitu citra hasil fusi Landsat 8 kombinasi band 567 dan citra TerraSAR-X ORRI dengan Citra TerraSAR-X DSM formasi ini mempunyai kenampakan warna hijau, biru, merah bata, dan kuning dengan dominasi warna paling banyak adalah warna hijau. Formasi ini memiliki pola aliran sungai trelis dan memiliki tekstur yang kasar. Bentuk morfologi pada formasi ini adalah bergelombang.

Formasi ini berada di Kecamatan Matup (Gresik) dan Sambeng (Lamongan). Memiliki pola yang tidak teratur, dikarenakan bentuk formasi bagian Barat berbeda dengan bentuk formasi bagian Timur. Formasi memiliki tutupan lahan berupa hutan lebat dan lahan kosong. Formasi ini berada di dekat formasi Tpm, dimana formasi Tpm (Formasi Mundu) memiliki morfologi yang lebih terjal dibandingkan Formasi Ledok. Formasi Ledok terdiri dari beberapa macam batuan yaitu: Napal pasiran bersisipkan batu lempung, batu pasir, batu gamping (Noya dkk., 1992). Formasi ini terbentuk pada masa Neozoikum zaman Tersier dengan kala Miosen.

Formasi Ledok berada di bawah Formasi Mundu dan di atas Formasi Wonocolo. Berdasarkan hubungan antar lapisan Formasi Ledok dan Formasi Wonocolo adalah selaras, yaitu memiliki stratigrafi yang sejenis. Formasi Ledok bagian atas mengandung banyak Glaukonit. Pada formasi ini ditemukan pula plankton/benton. Dimana semakin menuju ke formasi bagian atas, jumlahnya semakin berkurang. Umur Formasi Ledok adalah Miosen Akhir sekitar 24 juta tahun yang lalu, hal ini didasari penemuan plankton Globorotalia Plesiotumida (Susilohadi, 1995). Formasi ini memiliki beberada titik pengamatan antara lain titik 08MR142, 08MR143. Titik-titik penelitian ini mendiskripsikan batuan pada Formasi Ledok dengan warna abu kuning kecoklatan, getas.

4. Formasi Pucangan (Qtp)

Pada hasil kombinasi kedua citra yaitu citra hasil fusi Landsat 8 kombinasi band 567 dan citra TerraSAR-X ORRI dengan Citra TerraSAR-X DSM, formasi ini mempunyai kenampakan warna hijau kekuningan, merah bata dan biru. Sehingga menunjukkan bahwa formasi ini memiliki tutupan lahan berupa bangunan, vegetasi. Formasi ini memiliki pola yang tidak beraturan. Tekstur yang dimiliki oleh formasi ini adalah kasar dengan bentuk morfologi perbukitan terjal di bagian Selatan, sedangkan dibagian Utara formasi ini memiliki morfologi bergelombang. Formasi ini memiliki pola aliran sungai dendritik dibagian Utara karena morfologi relatif datar sedangkan dibagian selatan memiliki pola aliran sungai trelis dimana anak sungai dan induk sungai saling tegak lurus. Formasi ini berdekatan dengan Formasi Kalibeng (Tpmk) dan Formasi Kabuh (Qpk).

Formasi ini berada di Kecamatan Wringinanom, Kecamatan Dawarblandong dan Kecamatan Jetis. Formasi Pucangan terdiri dari beberapa macam batuan yaitu: breksi, batu pasir tufaan bersisipkan batu lempung dan konglomerat (Noya dkk., 1992). Formasi ini terbentuk pada zaman Kuarter, zaman ini dimulai pada tahun satu juta delapan ratus tahun yang lalu.

Formasi Pucangan memiliki lokasi di Selatan Pucangan antiklin. Formasi ini memiliki dua susunan yaitu batu lumpur bebiruan sampai abu-abu di bagian bawah dan susunan vulkanik di bagian atas. Bagian bawah dianggap sebagai sebagai Formasi Lidah dan bagian atas dianggap sebagai Formasi Pucangan. Formasi Pucangan 
berkembang di zona Kendeng pada awal Pleistosen. Formasi ini memiliki beberapa titik pengamatan antara lain titik 08MR174, 08MR185, 08MR186, 08MR187. Titik-titik penelitian ini mendiskripsikan batuan pada Formasi Mundu dengan warna abu - abu terang, berbutir halus, terpilah baik, porositas baik, getas.

5. Formasi Sonde (Tpso)

Pada hasil kombinasi kedua citra yaitu citra hasil fusi Landsat 8 kombinasi band 567 dan citra TerraSAR-X ORRI dengan Citra TerraSAR-X DSM Formasi Sonde memiliki warna gelap yaitu didominasi dengan warna hijau tua dan warna merah kecoklatan yang diselingi warna biru. Tekstur yang dapat dilihat dari kombinasi band di atas menunjukkan bahwa formasi ini memiliki tekstur yang kasar paling kasar di antara formasi lainnya yang terdapat pada wilayah penelitian. Pola Formasi Sonde tidak beraturan. Formasi ini memiliki pola aliran sungai trelis, ukuran formasi kecil dibandingkan dengan formasi di sekitarnya. Bentuk morfologi jika dilihat dari DSM dari citra TerraSar-X adalah berupa perbukitan terjal. Dari kombinasi band pada citra Landsat 8 menunjukan bahwa Formasi Sonde (Tpso) memiliki tutupan lahan sebagian besar hutan dan sebagian lagi lahan kosong. Pada Formasi Sonde terlihat dengan jelas jejak-jejak lapisan.

Formasi Sonde terdiri dari beberapa macam batuan yaitu: napal berselingan dengan batu pasir dan tuf [4]. Formasi ini terletak di Kecamatan Kabuh (Jombang), Sambeng (Lamongan), Kudu (Lamongan), Kemlagi (Lamongan), Dawarblandong (Gresik). Dalam formasi ini juga terdapat lipatan antiklin yang memanjang dari Barat ke Timur. Formasi ini terbentuk pada masa Neolitikum zaman Tersier pada kala Plestosen.

Formasi Sonde merupakan nama pengganti dari lapisan atas Formasi Kalibeng (Tmpk). Formasi ini terendapkan pada zona Kendeng selama Pleistosen akhir. Formasi ini dikenali oleh batu gamping bioklastik kasar dibagian bawah dan batu lempung pada bagian atas. [9].
Formasi ini memiliki bebepada titik pengamatan antara lain titik 08MR171, 08MR188, 08MR189, 08MR190. Titik-titik penelitian ini mendiskripsikan batuan pada Formasi Mundu dengan warna putih abu - abu kekuningan, berbutir halus, getas dan agak keras.

6. Formasi Mundu (Tpm)

Pada hasil kombinasi kedua citra yaitu citra hasil fusi Landsat 8 kombinasi band 567 dan citra TerraSAR-X ORRI dengan Citra TerraSAR-X DSM Formasi Mundu memiliki kenampakan warna hijau berseling biru dan merah kecoklatan. Tekstur yang dimiliki oleh formasi ini bervariasi dari kasar sampai halus, pada bagian Timur. Berdasarkan citra DSM TerraSAR-X formasi ini memiliki morfologi yang datar dibagian timur sedangkan pada bagian barat memiliki morfologi perbukitan. Formasi ini berdekatan dengan Formasi Lidah pada bagian Barat dan sebelah Utara dan endapan Aluvial pada bagian Timur. Formasi ini memiliki pola yang tidak seragam dan memiliki ukuran kecil. Formasi ini memiliki pola aliran sungai trelis. Formasi ini memiliki tutupan lahan berupa hutan, lahan kosong pada bagian Barat dan pemukiman di bagian Timur.

Formasi ini berada di Kecamatan Matup (Gresik) dan Sambeng (Lamongan), Kecamatan Kembangbahu (Gresik). Formasi Mundu terdiri dari beberapa macam batuan yaitu : Napal pasiran bersisipkan batu lempung, batu pasir, batu gamping (Noya dkk., 1992). Formasi ini terbentuk pada masa Neolitikum pada zaman Tersier dan kala Pleistosen.

Formasi Mundu berada di atas Formasi Ledok. Hubungan antara Formasi Mundu dan formasi di bawahnya adalah selaras. Formasi Mundu memiliki ketebalan yang belum jelas tapi pada lokasi yang bertempat $10 \mathrm{~km}$ di Utara Cepu, formasi ini memiliki ketebalah mencapai $340 \mathrm{~m}$. Formasi ini memiliki bebepada titik pengamatan antara lain titik 08MR139, 08MR144, 08MR145. Titik-titik penelitian ini mendiskripsikan batuan pada Formasi Mundu dengan warna putih, sebagian agak merah muda, kristalin, keras. 


\section{Formasi Kalibeng (Tmpk)}

Pada hasil kombinasi kedua citra yaitu citra hasil fusi Landsat 8 kombinasi band 567 dan citra TerraSAR-X ORRI dengan Citra TerraSAR-X DSM formasi ini memiliki warna hijau dan merah kecoklatan dengan berseling warna biru. Formasi ini memiliki pola yang tidak seragam, dan memiliki tekstur yang kasar. Formasi ini berada di antara Formasi Sonde (Tpso) dan Formasi Pucangan (Qtp). Pada wilayah ini terlihat dengan jelas jejak-jejak lapisan. Pola aliran sungai dari formasi ini adalah pola aliran trelis dimana arah aliran sungai dipengaruhi oleh arah perlapisan batuan. Sedangkan dari data DSM citra TerraSAR-X dapat diketahui morfologi daerah tersebut bervariasi dari morfologi bergelombang di bagian Utara formasi sampai terjal di bagian Selatan formasi. Formasi ini memiliki tutupan lahan vegetasi dan lahan kosong.

Formasi Kalibeng terdiri dari napal bersisipan batu pasir gampingan (Noya dkk., 1992). Formasi ini terletak pada Kecamatan Kabuh dan Kecamatan Kudu Kabupaten Jombang. Formasi ini terbentuk pada masa Neolitikum zaman Tersier dengan kala Miosen.

Formasi Kalibeng ditandai dengan warna kehijauan atau putih keabuan pada batuan lembung foraminiferal pada Miosen akhir sampai Pliocene awal. Formasi Kalibeng masuk dalam bentuk lapisan dasar Kalibeng yang dibagi menjadi dua yaitu bagian bawah (batu lempung) dan bagian atas (batu gamping dan batu lempung). Kemudian dilakukan proses penamaan, pada lapisan dasar Kalibeng diberi nama Formasi Kalibeng dan di bagian atas lapisan Kalibeng diberi nama Formasi Sonde.

Pada Formasi Kalibeng memiliki titik pengamatan 08MR237 dan 08 MR133. Titik pengamatan tersebut mendiskripsikan batuan pada Formasi Kalibeng dengan warna kelabu kekuningan, berbutir halus, keras.

8. Endapan Aluvial

Pada hasil kombinasi kedua citra yaitu citra hasil fusi Landsat 8 kombinasi band 567 dan citra TerraSAR-X ORRI dengan Citra TerraSAR-X DSM, formasi ini berwarna berwarna cerah yang didominasi dengan warna biru muda, biru kehijauan dan merah kecoklatan dengan dominasi warna paling banyak adalah warna biru muda. Formasi ini memiliki tekstur sedang. Endapan ini memiliki pola beraturan. Formasi ini memiliki tutupan lahan berupa lahan kosong, vegetasi (penggunaan lahannya berupa sawah dan ladang) dan pemukiman. Formasi ini memiliki pola sungai dendritik. Dan berdasarkan data Digital Surface Model dari citra TerraSAR-X formasi ini memiliki morfologi datar. Formasi Aluvium berada di dekat Formasi Lidah (QtI) dan Formasi Pucangan, di antara tiga formasi tersebut Formasi Aluvium yang memiliki morfologi yang paling datar.

Daerah yang banyak ditemukan endapan ini adalah di perbatasan Kabupaten Gresik dengan Kabupaten Lamongan dan Kabupaten Mojokerto. Formasi ini merupakan salah satu formasi yang memiliki ukuran yang besar pada wilayah penelitian.

Endapan aluvium memiliki penyusun yang terdiri dari kerakal, kerikil, pasir, lanau dan Lumpur [4]. Endapan ini terbentuk pada zaman Kuarter.

Titik pengamatan pada formasi ini antara lain adalah titik 08MR146 A, 08MR146B, 08MR146C dan 08MR146D. Titik pengamatan formasi tersebut memiliki deskripsi batuan dengan warna abu kecoklatan, halus, agak keras.

9. Formasi Kabuh (Qpk)

Pada hasil kombinasi kedua citra yaitu citra hasil fusi Landsat 8 kombinasi band 567 dan citra TerraSAR-X ORRI dengan Citra TerraSAR-X DSM, Formasi Kabuh memiliki kenampakan dengan warna biru muda, biru, jingga, merah kecoklatan dengan dominasi warna jingga. Formasi ini memiliki tekstur sedang sampai kasar. Formasi Kabuh memiliki pola tidak seragam, dan berdasarkan data Digital Surface Model dari citra TerraSAR-X morfologi daerah ini bergelombang sampai terjal. Formasi ini memiliki pola aliran sungai trelis, pola aliran sungai pada formasi ini dipengaruhi oleh 
perlapisan batuan. Formasi ini berada di antara Formasi Pucangan (Qtp) dan Formasi Lidah (QtI). Formasi Kabuh memiliki formasi lebih landai di antara Formasi Pucangan (Qtp) dan Formasi Lidah (QtI).

Formasi Kabuh ini terdiri dari batu pasir tufaan bersisipkan batu lempung, konglomerat dan tuf. Formasi ini terbentuk pada zaman Tersier. Formasi Kabuh berada di kecamatan Sambeng.

Formasi Kabuh berada di atas Formasi Pucangan, Formasi Kabuh berada di zona Kendeng dan mengalami proses pengendapan pada kala Pleistosen Tengah sekitar 900 ribu tahun yang lalu. Formasi Kabuh memiliki dua susunan utama, pertama terdiri dari batu lumpur laut dan batu pasir yang berada pada lapisan bawah dan kandungan vulkanik pasa lapisan bagian atas. Formasi ini memiliki beberada titik pengamatan antara lain titik 08MR151， 08MR168， 08MR167. Titik-titik penelitian ini mendiskripsikan batuan pada Formasi Mundu dengan warna kuning kecoklatan, berbutir sangat kasar, menyudut, terpilah buruk, porositas baik, karbonatan, dapat diremas (friable).

\section{Formasi Qc}

Endapan sungai merupakan formasi yang terletak di sepanjang Sungai Brantas. Dari Citra Landsat 8 kombinasi band 567 yang telah dilakukan proses fusi dengan citra Ortho Rectified Radar Image (ORRI) TerraSAR-X, formasi ini memiliki warna biru dengan bercak merah dan memiliki pola tidak beraturan seperti pada gambar. Endapan ini memiliki tekstur halus sampai sedang dengan morfologi relatif datar. Bentuk formasi ini adalah bulat. Bentuk dari formasi ini lebih kecil dari pada formasi yang berada disebelahnya yaitu formasi fluvial (Qf) dan formasi rawa (Qs).

Formasi ini memiliki pola aliran sungai radial, yang arah aliran sungainya menyebar dari lokasi tertentu. Ukuran dari formasi ini relatif kecil. Lapisan endapan sungai yang mempunyai material dengan tekstur menghalus ke arah atas (fining upward) kemudian tererosi oleh arus sungai berikutnya yang kemungkinan telah berpindah dan menggerus endapan sungai yang lebih tua. Setelah membuat alur kemudian terbentuklah endapan yang lebih mudah pada alur yang telah tererosi tersebut dan diisi oleh material berukuran pasir. Kemudian endapan yang terakhir ini juga menutupi endapan sedimen yang lebih tua tadi secara keseluruhan (Imran dkk.,2011)

\section{Formasi Qs}

Berdasarkan hasil fusi dari citra Landsat 8 kombinasi 567 dan citra biru muda dan merah kecoklatan. Formasi ini memiliki tekstur sedang dan bentuk bulat memanjang dan beberapa bagian persegi. Pola pada formasi ini adalah tidak seragam. Formasi ini memiliki pola aliran sungai dendritik atau berbentuk seperti ranting pohon dan morfologi daerah yang datar.

Formasi ini tersusun oleh lanau, lumpur, lempung dan gambut. Formasi ini berada di wilayah Kecamatan Gedek, Kecamatan Jetis dan Kecamatan Kudu. Ukuran dari formasi ini adalah sedang.

\section{Formasi Qf}

Formasi Fluvial berada diselatan formasi campuran. Formasi ini memili warna biru muda berseling hijau, merah bata, merah kecoklatan. Tekstur yang dimiliki formasi ini halus sampai dengan sedang. Formasi ini berbentuk bulat memanjang dan memiliki pola yang tidak teratur.

Pola aliran yang dimiliki formasi ini adalah dendritik. Ukuran dari formasi ini adalah sedang. Formasi ini berada di Kecamatan Kesamben Kabupaten Jombang, Kecamatan Tebalang Kabupaten Jombang, Kecamatan Peterongan Kabupaten Jombang, Kecamatan Prajrit Kulon Kabupaten Mojokerto dan wilayah Kota Mojokerto.

\section{Kelurusan Batuan}

Kelurusan adalah semua pola berupa garis lurus yang muncul karena tingkat kecerahan pada permukaan tanah dalam foto udara atau citra satelit. Kelurusan juga menyebabkan terputusnya litologi batuan. Pada hasil intepretasi citra Landsat 8 
dan citra TerraSAR-X terdapat kelurusan di Formasi Sonde, Kalibeng dan Mundu.

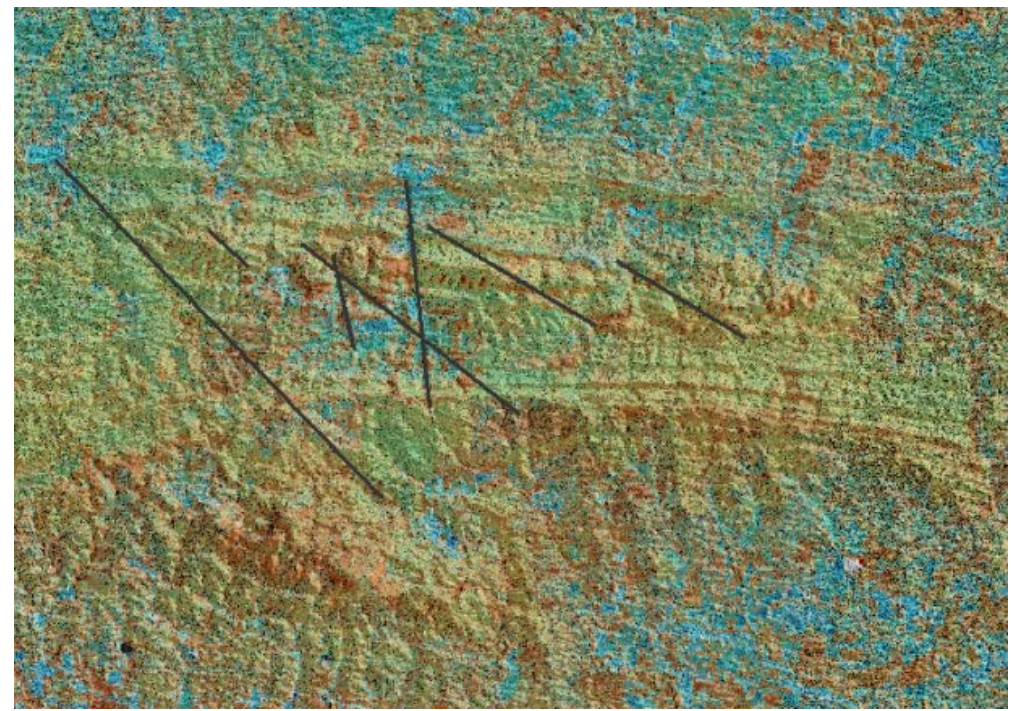

Gambar 6. Kenampakan Kelurusan pada Formasi Kalibeng (Tmpk) dan Sonde (Tpso)

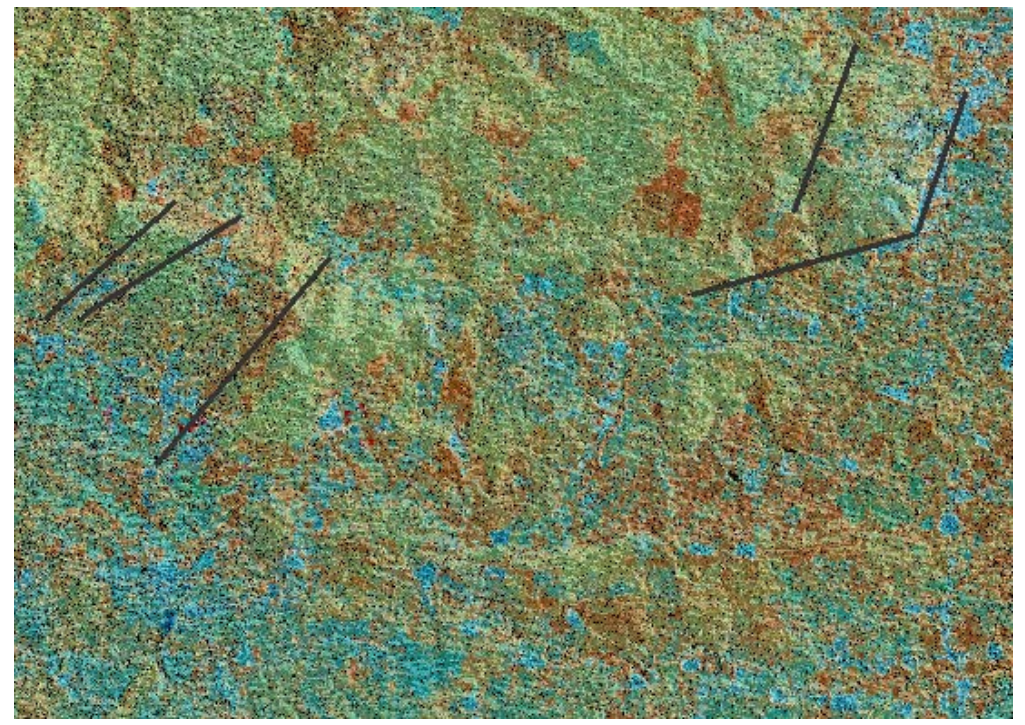

Gambar 7. Kenampakan Kelurusan pada Formasi Mundu (Tpm)

\section{Penelitian Terdahulu}

Pada penelitian mengenai pemetaan geologi menggunakan citra satelit yang telah dilakukan sebelumnya, terdapat persamaan yaitu pada endapan aluvium pada wilayah Wonosari, endapan alluvium sama-sama diidentifikasi memiliki warna cerah, pola aliran dendritik, dan memiliki tutupan lahan ladang dan pemukiman (Hanafi dkk., 2010). Sedangkan pada wilayah Takalar-Sapaya memiliki endapan alluvial dengan kandungan berupa lempung hitam, lumpur dan lanau (Reditya dkk., 2010). Sedangkan pada penelitian Lembar Mojokerto ini endapan alluvial memiliki kandungan kerakal, kerikil, pasir, lanau dan lumpur (Purwadhi, 2001).

Pada penelitian di daerah Nangapinoh endapan alluvium juga memiliki warna cerah dengan warna biru dan coklat. Formasi ini memiliki morfologi yang landai dengan pola sungai dendritik (Ismawati dkk., 2014). 
Perbandingan Hasil Intepretasi Citra Satelit dengan Peta Geologi 1:100.000

Terdapat perbedaan formasi antara peta geologi 1:100.000 dengan peta geologi hasil intepretasi citra. Perbedaan formasi tersebut adalah munculnya formasi baru pada peta hasil intepretasi citra Landsat 8 dan TerraSAR-X. formasi tersebut adalah Formasi Endapan Fluvial, Formasi Endapan Sungai dan Formasi Endapan Rawa. Sedangkan pada peta geologi 1:100000 ketiga formasi di atas masuk dalam Formasi Aluvial.

Pemisahan ketiga formasi diatas dengan endapan alluvial dilihat dari perbedaan kunci interpretasi citra, morfologi dan pola aliran sungai dari ketiga formasi tersebut dengan formasi alluvial. ketepatan interpretasi dari penelitian ini dapat diketahui dengan menggunakan rumus:

$$
K L=\frac{j K L}{j S L} * 100 \%
$$

\section{Dimana:}

$\mathrm{KI}=$ Ketepatan interpretasi

$\mathrm{JKL}=$ Jumlah kebenaran interpretasi

$J S L=$ Jumlah sampel lapangan

Sehingga ketepatan interpretasi yang didapat dari penelitian ini adalah:

$$
\begin{aligned}
K L & =\frac{9}{12} * 100 \% \\
& =75 \%
\end{aligned}
$$

Hasil tersebut tidak masuk dalam nilai ambang akurasi, dimana nilai ambang akurasi adalah 85\% [11]. Hal ini dapat disebabkan perbedaan metode pemetaan yang digunakan antara pemetaan manual yang dilakukan oleh badan geologi dan pemetaan pada penelitian ini yang menggunakan metode interpretasi data penginderaan jauh.

\section{PENUTUP}

\section{Simpulan}

Dari hasil dan analisa yang telah dilakukan maka kesimpulan yang dapat diambil adalah
1. Pada proses interpretasi citra gabungan menggunakan kunci interpretasi formasi-formasi batuan yang terdapat pada daerah penelitian antara lain Formasi Kabuh, Formasi Pucangan, Formasi Mundu, Formasi Sonde, Formasi Notopuro, Formasi Lidah, Formasi Ledok dan Endapan Aluvium.

2. Terdapat perbedaan antara peta hasil Intepretasi dengan peta geologi 1:100.000 yaitu perbedaan formasi batuan. Pada peta hasil interpretasi citra terdapat 12 formasi batuan sedangkan pada peta Geologi 1:100000 ada 9 formasi batuan. Sehingga ketetapan akurasi pada daerah ini adalah $75 \%$.

3. Berdasarkan proses pengolahan dari citra Landsat 8 dengan citra TerraSAR-X didapatkan hasil formasi terbesat adalah Formasi Swamp atau Formasi Rawa dengan luas $147 \mathrm{Km}^{2}$ dan formasi terkecil adalah Formasi Notopuro dengan luasan $12 \mathrm{~km}^{2}$. Selain itu, pada peta geologi hasil interpretasi citra ini terlihat kelurusan batuan pada Formasi Kalibeng, Sonde dan Mundu.

\section{DAFTAR PUSTAKA}

Noor, D., 2011. Geologi untuk Perencanaan. Yogyakarta: Graha IImu.

Badan Geologi. September 2013. <URL: http//psg.bgl.esdm.gi.id/geosains/331-peran-petageologi-dalam-pembangunan-nasional>.Dikunjungi pada tanggal 18 Januari 2013, pukul 08.71

Purwadhi, F. H., 2001. Interpretasi Citra Digital. Jakarta: PTGramedia Widiasarana Indonesia.

Noya Y., Suwarti T., Harsono dan Sarmili L., 1992. Peta Geologi Lembar Mojokerto Jawa Timur. Pusat Penelitian dan Pengembangan Geologi, Indonesia. Bandung.

NASA Remote Sensing Tutorial Web Page.http//rst.gsfc.nasa.gov/.

Hanafi, R.A., Sukojo, B.M.,dan Ipranta., 2010. Pemetaan Geologi Dengan Menggunakan Data Citra Alos di Daerah Pegunungan Selatan (Kabupaten WonogiriJawa Tengah). Tugas Akhir Jurusan Teknik Geomatika, Surabaya.

Reditya, I.W.,, Sukojo, B.M.,dan Ipranta., 2010. Analisa Integrasi Citra Ifsar dan Landsat Untuk Pembuatan Peta Geologi Daerah Takalar-Sapaya Propinsi Sulawesi Selatan. Tugas Akhir Jurusan Teknik Geomatika, Surabaya 
Ismawati, Desi, Sukojo, B.M.,dan Ipranta., 2014. Pemetaan Geologi Skala 1:50000 dengan Menggunakan Citra Radarsat 2 dan Landsat 8 (Studi Kasus : Nangapinoh Provinsi Kalimantan Barat). Tugas Akhir Jurusan Teknik Geomatika, Surabaya.

Susilohadi., 1995. Late tertiary and Quaternary Geology of The East Java Basin, Indonesia. Australia: Disertasi Jurusan Filosofi

Imran, A., Azikin, B., HL, R., \& Susilawati., 2011. Survei Lapangan Endapan Sedimen Kuarter di Sungai Mangottong di Kabupaten Sinjai (Studi Pendahuluan). - (pp. -). Jurusan Geologi Fakultas Teknik Universitas Hasanudin, Makasar

Febrianto, A., 2006. Interpretasi Citra Satelit SPOT 5 Untuk pemetaan Penggunaan Lahan Kecamatan Semarang Barat Kota Semarang. Universitas Negeri Semarang, Semarang. 